\title{
Aplikasi E-Voting Untuk Pemilihan Ketua OSIS di SMA XYZ Berbasis Web Responsive
}

\author{
Dahnial \\ Program Studi Ilmu Administrasi Negara \\ STIA Satya Negara \\ Palembang, Indonesia \\ dahnial_dp@yahoo.com
}

\begin{abstract}
Student council election is a routine school activity every year, but currently the student council election is done manually using ballot papers containing the candidates. The weakness of this system is in addition to the process of getting longer results, it is also prone to fraud due to the excess of manipulated ballot papers, as well as being less environmentally friendly. Therefore the need for a system that is able to provide solutions to these problems, one of which is a responsive web-based student council election system. Web-based systems are more common than mobile-based systems, because they are supported by all device platforms, different if only based on mobile (Android), only devices based on the Android operating system can use the application. Moreover, web technology is now very good, responsive web allows the display of web pages to adjust to the user's screen size automatically, responsive web framework used in this study is bootstrap. In this study, researchers used a software development model which is a prototype. And for the tools used in developing this application is the Unified Modeling Language, and the system testing method uses a blackbox. The results of this study can provide results in the form of a system that is fast and accurate in providing conclusions on the election of student council president, cost-effective and environmentally friendly.
\end{abstract}

Keywords: e-voting, bootstrap, prototype

Abstrak-- Pemilihan ketua OSIS merupakan kegiatan rutin sekolah tiap tahunnya, akan tetapi saat ini pemilihan ketua OSIS dilakukan secara manual menggunakan kertas surat suara yang berisikan para kandidat. Kelemahan sistem ini selain proses untuk mendapatkan hasil yang lebih lama, juga rentan terjadinya tindak kecurangan karena kelebihan kertas suara yang dapat dimanipulasi, selain itu kurang ramah lingkungan.. Oleh karena itu perlunya sebuah sistem yang mampu memberikan pemecahan masalah tersebut, salah satunya sistem pemilihan ketua OSIS berbasis web yang responsive. sistem berbasis web lebih umum dibandingkan sistem berbasis mobile, karena didukung oleh semua platform perangkat, berbeda jika hanya berbasis mobile (android), hanya perangkat dengan basis sistem operasi android yang dapat menggunakan aplikasi tersebut. Apalagi teknologi web saat ini sudah sangat baik, web responsive memungkinkan tampilan halaman web akan menyesuaikan dengan ukuran layar perangkat pengguna secara otomatis, framework web responsive yang digunakan dalam penelitian ini adalah bootstrap. Dalam penelitian ini, peneliti menggunakan model pengembangan perangkat lunak yang merupakan prototipe. Dan untuk alat yang digunakan dalam mengembangkan aplikasi ini adalah Unified Modeling Language, serta metode pengujian sistem menggunakan blackbox. Hasil penelitian ini dapat memberikan hasil berupa sistem yang cepat dan akurat dalam memberikan kesimpulan pemilihan ketua OSIS, hemat biaya serta ramah lingkungan.

Kata Kunci: e-voting, bootstrap, prototype

\section{PENDAHULUAN}

Perkembangan teknologi dan ditunjang dengan akses internet yang sudah semakin baik saat ini membuat akses ke sumber informasi menjadi lebih mudah. Dibidang komunikasi saat ini setidaknya ada 2 (dua) teknologi yang berkembang pesat, yaitu smartphone dan komputer berjaringan internet, yaitu komputer yang dapat menghubungkan seseorang dengan orang lain tanpa adanya batasan jarak dan waktu [1]. Dengan menggunakan perangkat mobile seperti smartphone, masyarakat dapat mengakses berbagai informasi yang dibutuhkan saat itu juga. Dan salah satu bentuk teknologi informasi yang paling banyak digunakan untuk berbagi informasi adalah website. Website sendiri merupakan media yang berfungsi sebagai media penyampai informasi di internet. Macamnya, bisa sebagai penyampai informasi komersial (toko online), service (layanan web sms), dan penyampai berita (aplikasi surat kabar online). Website dibentuk dan diciptakan dari serangkaian script atau kode tertentu dari bahasa pemrograman tertentu [2]. OSIS sebagaitempat kehidupan berkelompok siswa bekerjasama untuk mencapai tujuanbersama. Dalam hal ini OSIS dipandang sebagai sistem, dimana sekumpulan para siswa mengadakan koordinasi dalam upaya menciptakan suatu organisasi yangmengadakan koordinasi dalam upaya menciptakan suatu organisasi yang mampumencapai tujuan [3]. Dalam memenuhi kewajiban pemilihan ketua OSIS, maka penyelenggaraan pemilihan ini dilakukan oleh pengurus lama, dimana pemilihnya adalah seluruh siswa disekolah tersebut. pemilihan ketua OSIS selama ini dilakukan secara manual. Kelemahan sistem ini selain proses untuk mendapatkan hasil yang lebih lama, juga rentan terjadinya tindak kecurangan karena kelebihan kertas suara yang dapat dimanipulasi, selain itu kurang ramah lingkungan. Oleh karena itu perlunya sebuah sistem yang mampu memberikan pemecahan masalah tersebut, salah satunya sistem pemilihan ketua OSIS berbasis web yang responsive. sistem berbasis web lebih umum dibandingkan sistem berbasis mobile, karena didukung oleh semua platform 
perangkat, berbeda jika hanya berbasis mobile seperti android, hanya perangkat dengan basis sistem operasi android yang dapat menggunakan aplikasi tersebut. Apalagi teknologi web saat ini sudah sangat baik, web responsive memungkinkan tampilan halaman web akan menyesuaikan dengan ukuran layar perangkat pengguna secara otomatis, framework web responsive yang digunakan dalam penelitian ini adalah bootstrap. Bootstrap adalah platform untuk membuat tampilan dari sebuah halaman web dan aplikasi berbasis web. Bootstrap berisi kode html dan css yang telah dilengkapi desain untuk tipografi, bentuk, tombol, navigasi, dan lain sebagainya. Bootstrap bertujuan untuk meringankan pembuatan dan pengembangan web [4]. Bootstrap merupakan framework front end yang menggunakan HTML, CSS dan javascript yang dapat membuat aplikasi web yang responsive dan dapat digunakan pada lingkungan perangkat mobile [5]. Dalam penelitian ini ada beberapa jurnal yang menjadi referensi, antara lain: Rancang Bangun Aplikasi M-Voting Untuk Pemilihan Ketua OSIS Di Ma Darussalam Pangkalpinang Berbasis Smartphone Android [6]. Rancang Bangun Aplikasi E-Voting Berbasis Android (Studi Kasus: Pemilihan Ketua Organiasi di Lingkungan Fakultas Teknik Universitas Tanjungpura) [7]. Rancang Bangun E-Voting Berbasis Website di Universitas Negeri Surabaya [8]. Perancangan Sistem E-Voting Untuk Pemilihan Ketua OSIS SMP Negeri 10 Pekanbaru [9]. Perancangan E-Voting Untuk Pemilihan Bem Berbasis Web [10].

\section{METODE PENELITIAN}

Metode yang peneliti gunakan dalam pengumpulan data adalah studi literatur, yaitu mengumpulkan bahan kajian berupa jurnal maupun buku yang terkait dengan penelitian yang sedang penulis lakukan. Sedangkan model pengembangan sistem yang penulis gunakan adalah prototype, dan alat bantu pengembangan sistem yang digunakan adalah UML (Unified Modeling Language), serta metode pengujian menggunakan blackbox.

\section{A. Model Pengembangan Sistem}

Prototype merupakan sesuatu yang harus dievaluasi dan di modifikasi kembali, segala perubahan dapat terjadi pada saat prototype dibuat untuk memenui kebutuhan pengguna dan pada saat yang sama memungkinkan pengembang untuk lebih memahami kebutuhan pengguna secara lebih baik [11].

Tahapan - tahapan dalam model prototype antara lain [12]:

\section{1) Komunikasi}

Pada tahap ini, dilakukan identifikasi masalah dan kebutuhan sistem melalui komunikasi yang intensif dengan pengguna.

2) Perencanaan secara cepat

Perencanaan secara cepat disini berfokus pada representasi semua aspek perangkat lunak yang terlihat oleh pengguna akhir dalam bentuk mock up tampilan yang dibuat dari kertas, yang menggambarkan antarmuka tampilan sistem.

3) Pemodelan perancangan secara cepat

Pemodelan menggunakan UML Diagram seperti Use Case Diagram, Activity Diagram, Sequence Diagram, dan Class Diagram. Pemodelan pertama yang dilakukan adalah activity diagram. Diagram ini menggambarkan bagaimana sistem pemilihan selama ini dilakukan di SMA XYZ, adapun gambar dari proses tersebut ditunjukkan pada gambar 1:

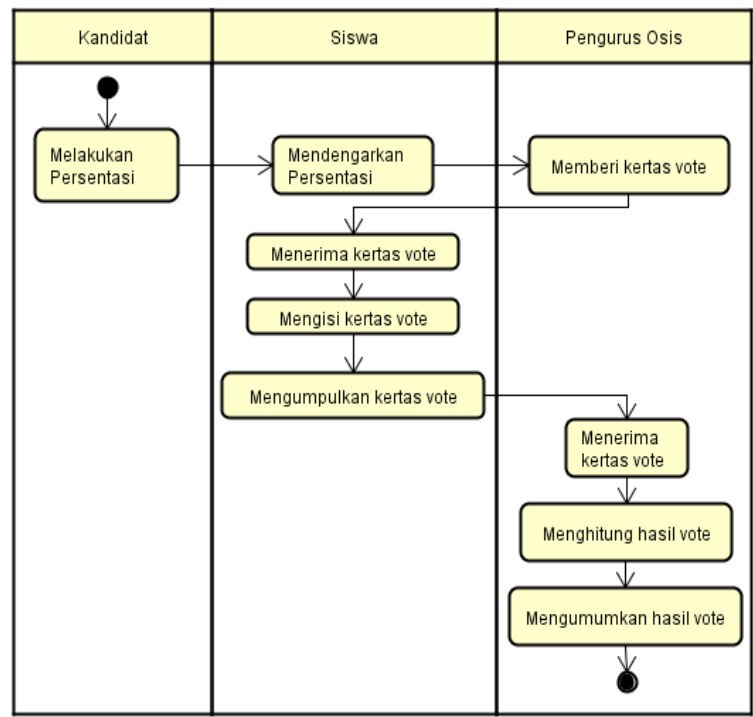

Gambar 1. Activity Diagram Sistem Berjalan

Diketahui bahwa proses pemilihan ketua OSIS ini akan diawali dengan presentasi visi dan misi dari para kandidat, lalu siswa yang telah mendengarkan presentasi akan mendapatkan kertas suara dari pengurus OSIS yang menjadi panitia pemilihan, selanjutnya apabila siswa telah memilih, maka kertas suara akan dikumpulkan lagi ke panitia pemilihan. Lalu selanjutnya panitia akan melakukan perhitungan apabila seluruh siswa telah memilih para kandidat. Kemudian barulah setelah perhitungan akan diumumkan siapa yang terpilih sebagai ketua OSIS periode berikutnya di SMA XYZ. Untuk masa bakti 1 tahun kedepan. Diagram kedua yang dibuat adalah use case diagram Sistem Usulan Admin. Sistem $e$ voting nantinya akan memiliki beberapa menu yang dapat digunakan oleh administrator, dimana akan ditunjukkan pada gambar 2:

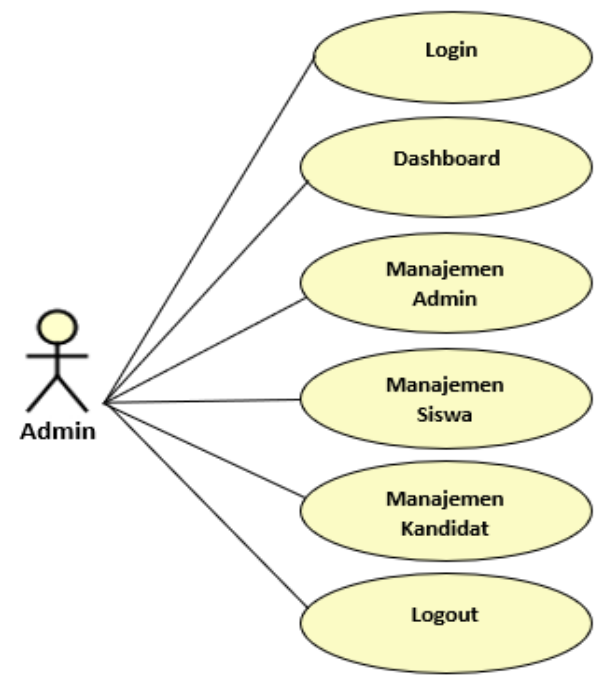

Gambar 2. Usecase Diagram Sistem Usulan admin 
Administrator untuk dapat mengelola sistem harus login terlebih dahulu, kemudian akan diarahkan ke halaman dashboard, lalu didalam dashboard akan ada menu manajemen admin yang berfungsi untuk menambahkan atau menghapus akun administrator, lalu menu manajemen siswa yang berfungsi untuk membuat akun bagi siswa agar dapat masuk kedalam sistem untuk memberikan hak suara, kemudian ada manajemen kandidat yang berfungsi untuk menambahkan atau menghapus siswa yang menjadi kandidat ketua OSIS, dan yang terakhir adalah logout yang berfungsi untuk keluar dari hak akses administrator.

Selanjutnya yang ketiga adalah use case diagram Sistem Usulan Siswa. Pada gambar 3 terlihat gambaran dari menu yang akan dimiliki oleh para pengguna yakni siswa SMA XYZ.

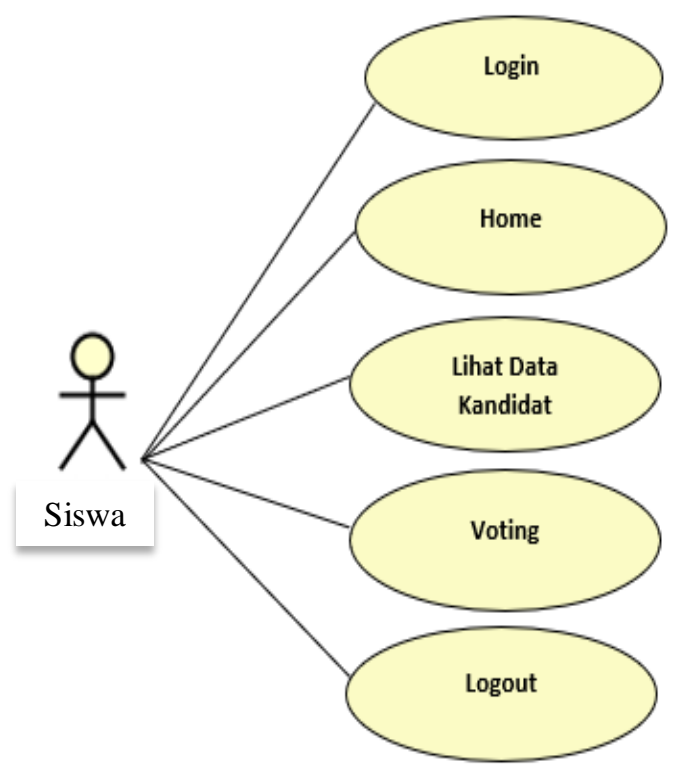

Gambar 3 Use case Diagram Sistem Usulan Siswa

Adapun menu dari aplikasi ini antara lain login, dimana siswa dapat menggunakan username dan password yang sudah diberikan sebelumnya. Hanya siswa yang terdaftar saja yang akan memiliki akun untuk masuk ke sistem dan memberikan hak suara. Lalu setelah login maka siswa akan diarahkan ke halaman home atau dashboard, dimana pada halaman home atau dashboard ini terdapat menu lihat kandidat, voting, serta logout. Menu lihat kandidat berisi foto kandidat dan visi misi dari kandidat tersebut, sedangkan menu voting berisi tampilan daftar kandidat yang bisa dipilih. Dan terakhir adalah menu logout yang berfungsi untuk keluar dari hak akses siswa dari dalam sistem.

Pemodelan keempat berupa activity diagram lihat voting sistem usulan Admin. Adapun activity diagram lihat voting admin pada gambar 4 menjelaskan bagaimana cara admin mendapatkan hasil pemilihan dari aktivitas pemilihan yang telah selesai dilakukan.

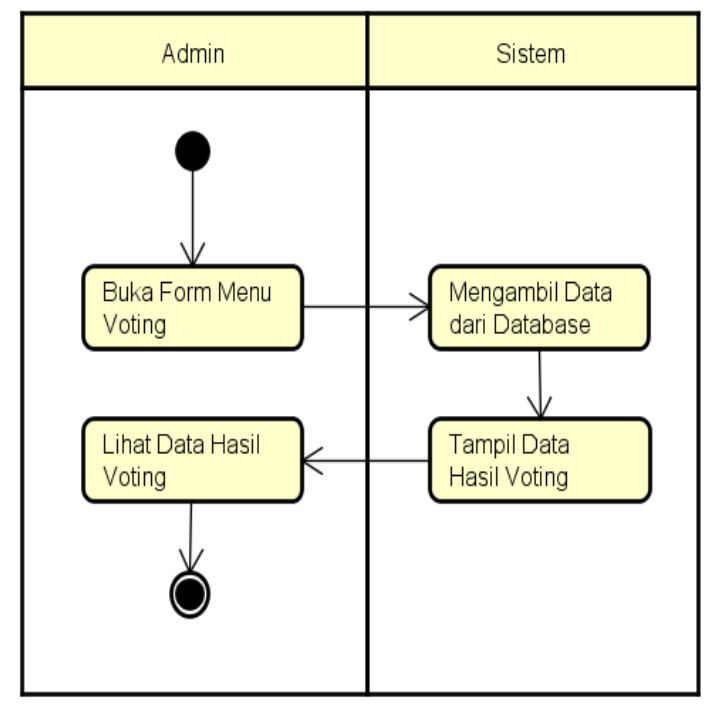

Gambar 4. Actvity Diagram Lihat Voting admin

Admin dapat mengambil data suara dengan cara memilih lihat data hasil voting, dan sistem akan menampilkan data hasil pemilihan secara menyeluruh. Dan pemodelan kelima berupa activity diagram menu voting sistem usulan siswa.

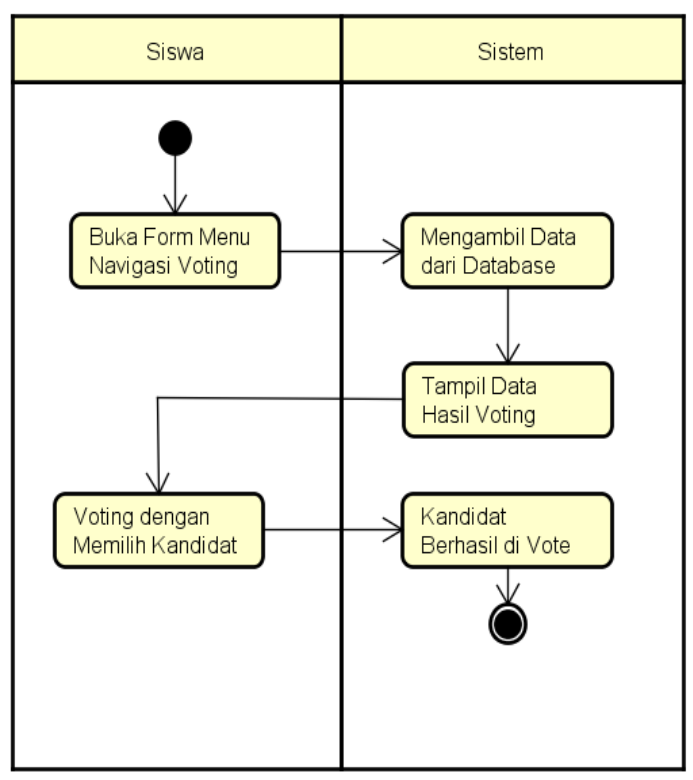

Gambar 5. Actvity Diagram Menu Voting Siswa

Dari gambar 5 terlihat siswa saat akan memberikan suara dengan cara masuk kedalam sistem lalu akan tampil data hasil voting terakhir, dan siswa dapat langsung menentukan kepada kandidat yang mana suara akan diberikan. Selanjutnya apabila sudah memilih, maka presentase suara akan berubah yang berarti kandidat sudah dipilih atau divote.

Pemodelan keenam berupa sequence diagram sistem usulan admin. Diagram ini akan menggambarkan urutan kerja sistem saat admin sedang menggunakan sistem. Antara lain dashboard atau menu voting, data kandidat, data siswa dan data vote. 


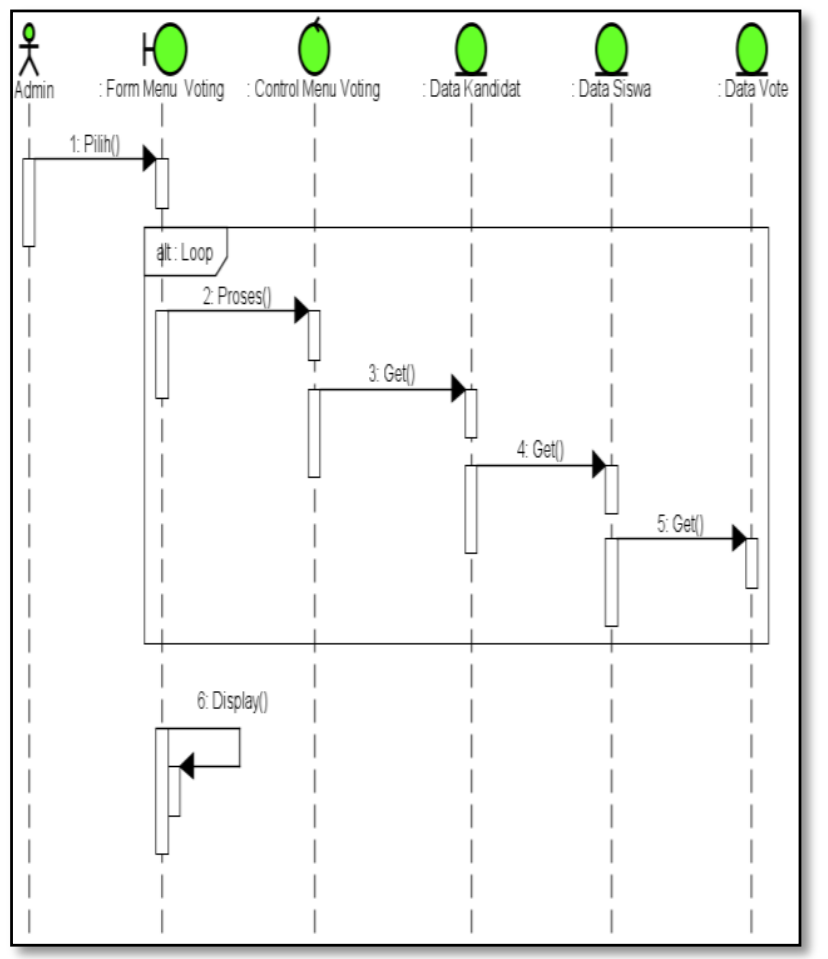

Gambar 6. Sequence usulan admin

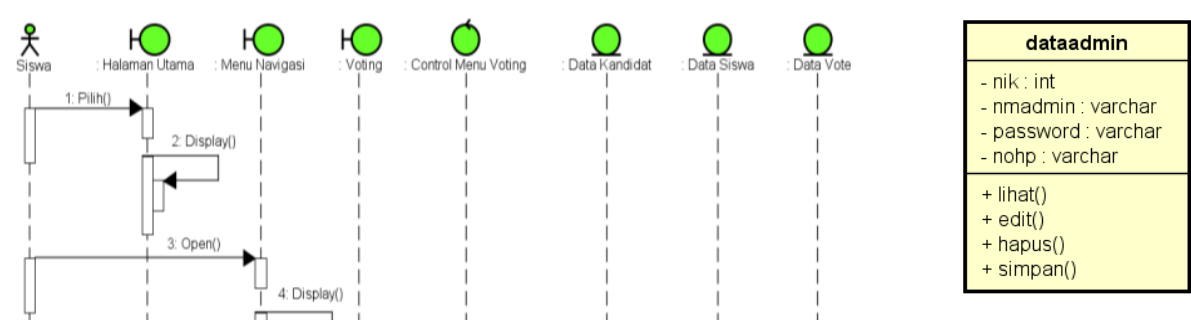

\section{PEMBAHASAN}

Dalam bagian pembahasan ini dilakukan tahapan ke empat dalam model prototype, yaitu pembentukan prototype. Pada tahap ini dibuat prototype yang mewakili sistem yang akan dibangun oleh peneliti sesuai dari data pemodelan pada diagram UML yang telah dilakukan pada tahapan sebelumnya.

\section{A. Tampilan Antarmuka Sistem}

Berikut ini merupakan gambar tampilan dari aplikasi pemilihan ketua OSIS berbasis web di SMA XYZ yang dapat diakses oleh pemilih. 


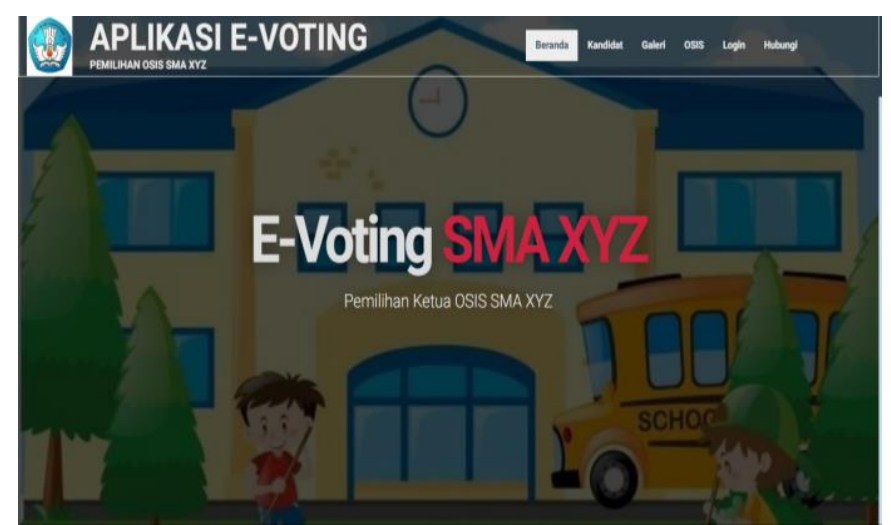

Gambar 9. Tampilan Antarmuka Aplikasi

Pada gambar 9 menunjukkan tampilan antarmuka dari web saat diakses oleh pengguna, dimana untuk bisa memberikan hak suara, maka pengguna harus login atau masuk kedalam sistem terlebih dahulu.

\section{APLIKASI E-VOTING}

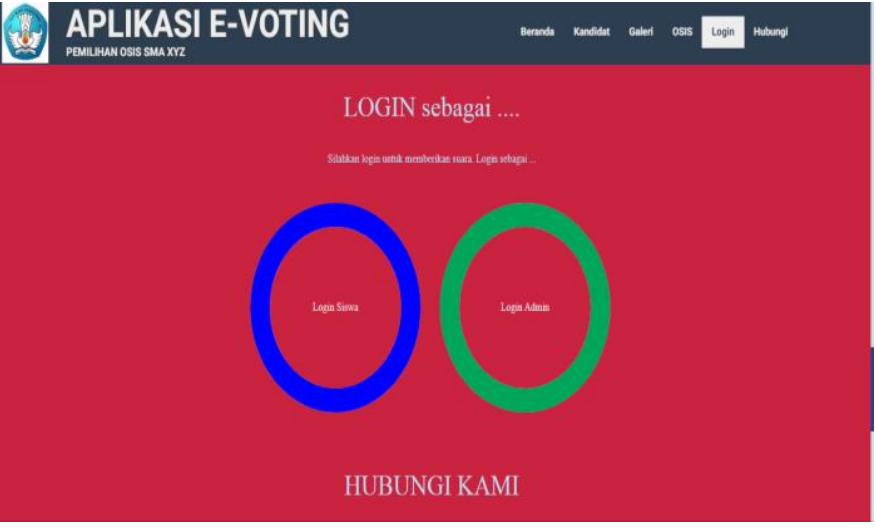

Gambar 10. Tampilan Antarmuka login

Gambar 10 menunjukkan tampilan saat pengguna ingin login kedalam sistem dengan cara memilih menu login sesuai hak akses yang dimiliki, dari gambar 10 terlihat terdapat dua menu login yang bisa digunakan oleh admin dan siswa. Untuk dapat masuk kedalam sistem pengguna diharuskan untuk memasukkan username dan password yang dimiliki.

\section{B. Tampilan Antarmuka Admin}

Untuk bisa menggunakan sistem maka pengguna harus mengisi username dan password yang dimiliki kedalam field yang telah disediakan, seperti yang terlihat pada gambar 11, lalu setelah memasukkan username dan password, pengguna bisa memilih tombol login.

Apabila pengguna memasukkan username atau password yang benar maka akan diarahkan kedalam halaman dashboard admin seperti yang ditampilkan pada gambar 13. Akan tetapi apabila username dan password yang dimasukkan salah maka akan ada pemberitahuan seperti yang ditunjukkan pada gambar 12.

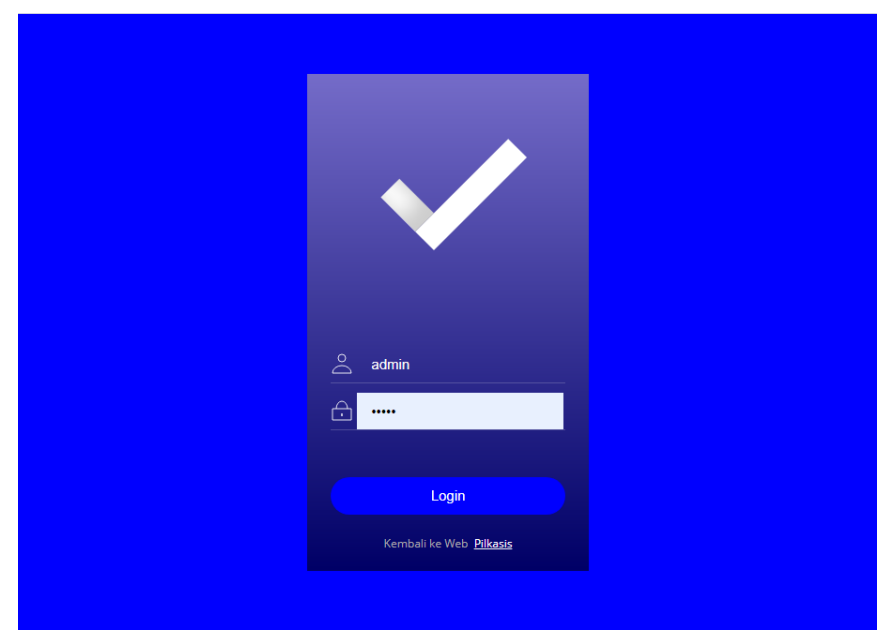

Gambar 11. Tampilan Login Admin

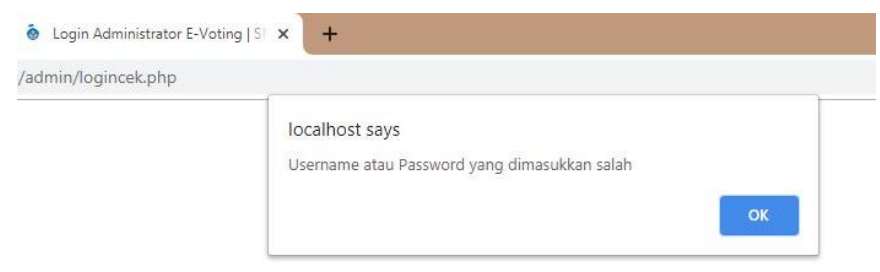

Gambar 12. Tampilan username atau password salah

Setelah pengguna berhasil melakukan login, maka akan diarahkan sesuai dengan hak akses yang dimiliki. Apabila hak aksesnya adalah administrator maka, akan diarahkan ke halaman dashboard administrator, namun jika hak akses dari akun yang dimiliki merupakan siswa, maka akan diarahkan ke dashboard siswa.

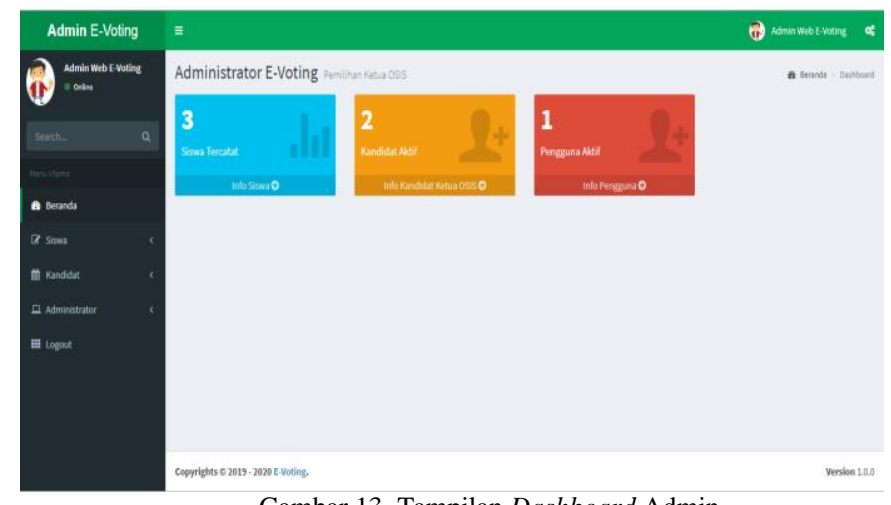

Gambar 13 menunjukkan tampilan dari dashboard hak akses admin. Didalam hak akses ini admin bisa menambahkan data siswa melalui menu siswa apabila ada siswa baru yang masuk disekolah, begitu juga apabila ingin menghapus data siswa yang sudah lulus dan tidak memiliki hak suara lagi, tampilan manajemen siswa dapat diakses dari menu siswa, 
dimana tampilannya akan berupa tabel yang berisi data akun siswa, seperti yang ditunjukkan pada gambar 14 .
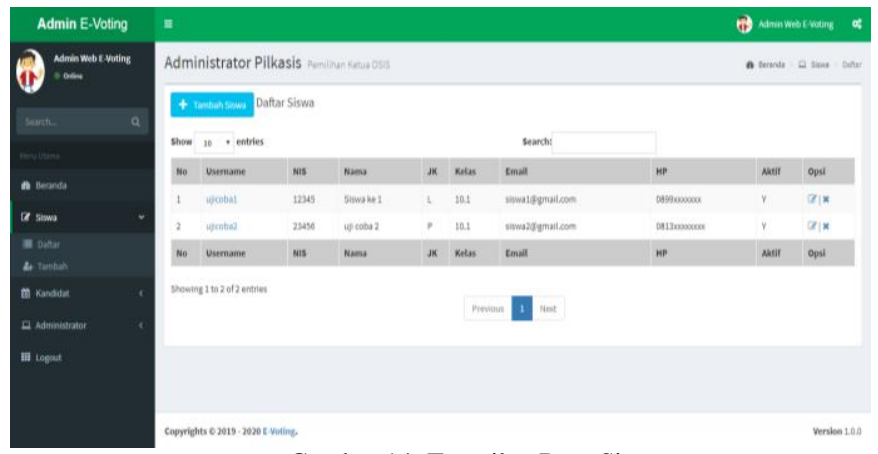

Gambar 14. Tampilan Data Siswa

Admin juga dapat menambahkan ataupun menghapus maupun mengganti data calon ketua OSIS dengan cara memilih menu kandidat seperti yang ditunjukkan pada gambar 15.

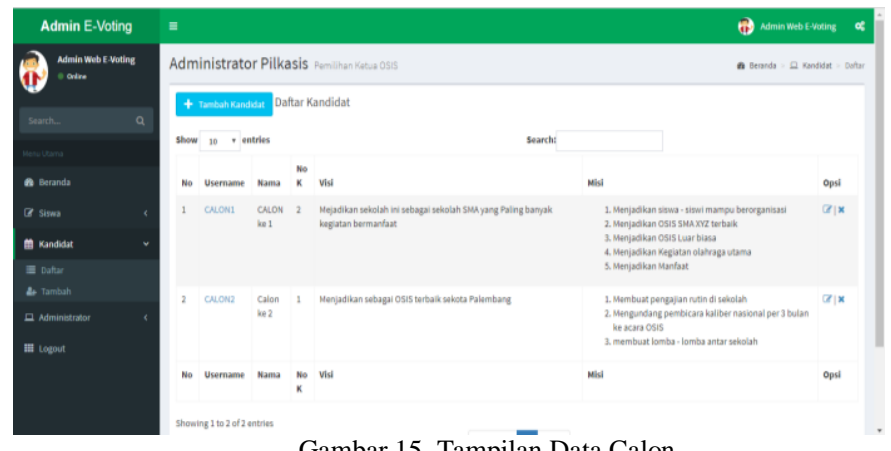

Gambar 15. Tampilān Data Calon

Data kandidat akan ditampilkan pada menu kandidat yang berisi foto kandidat, visi dan misi serta hasil voting sementara. Selain itu admin juga dapat menambah data admin baru untuk mengelola aplikasi ini, dengan cara memilih menu administrator untuk mengisi data - data yang diperlukan pada bagian sub menu tambah admin. Seperti yang terlihat pada gambar 16.
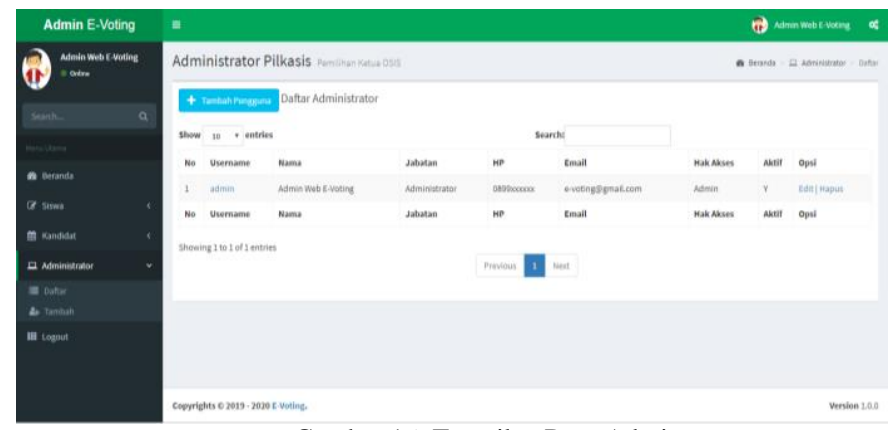

Gambar 16. Tampilan Data Admin

\section{Tampilan Antarmuka Siswa}

Siswa dapat memilih menu login siswa, kemudian siswa diharuskan mengisi username dan password kedalam field yang disediakan dimana tampilannya ditunjukkan pada gambar 17.

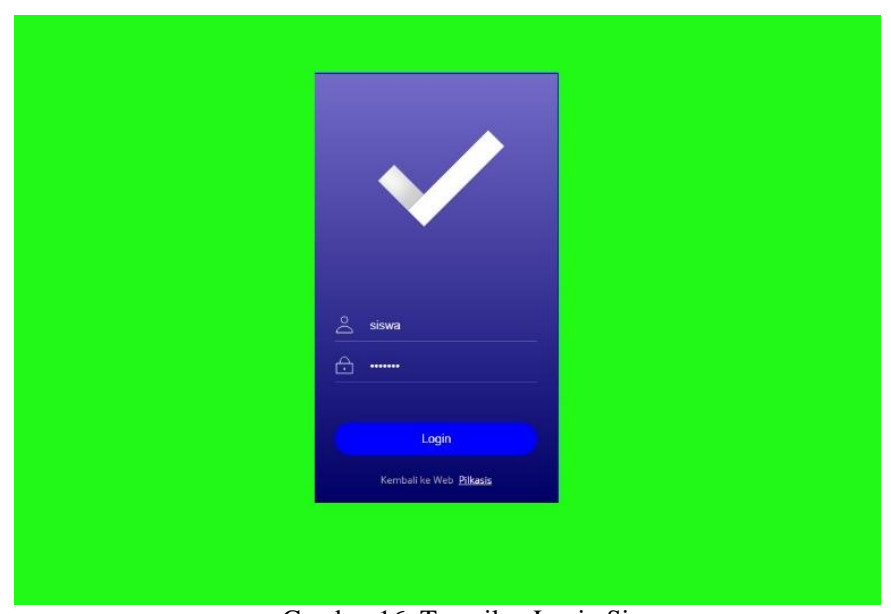

Gambar 16. Tampilan Login Siswa

Apabila siswa login kedalam aplikasi, menggunakan username atau password yang salah, atau menggunakan akun yang belum diaktivasi oleh administrator maka siswa tersebut akan mendapat pemberitahuan seperti yang ditunjukkan pada gambar 17. Akan tetapi jika siswa memasukkan username dan password yang benar dan sudah di aktivasi oleh administrator, maka akan diarahkan ke dashboard siswa, seperti yang ditunjukkan pada gambar 18.

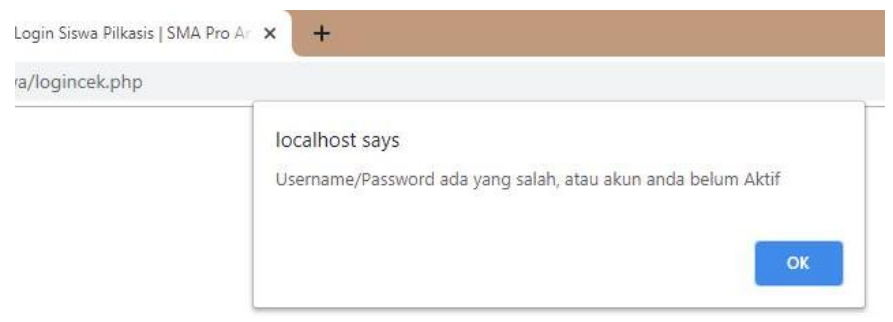

Gambar 17. Tampilan siswa gagal login

Apabila siswa berhasil login, maka siswa akan diarahkan ke halaman dashboard siswa pada aplikasi seperti yang ditunjukkan pada gambar 18, dimana pada halaman dashboard siswa dapat langsung melihat kandidat dari ketua OSIS yang akan dipilih, selain itu terdapat juga keterangan berupa perolehan suara sementara. Untuk bisa memilih, siswa tinggal memilih salah satu kandidat dengan cara menekan link atau tautan yang tertulis pilih kandidat pada bagian bawah kotak yang berisi foto dari kandidat ketua OSIS. Selain itu siswa juga dapat melihat profil dirinya pada bagian menu profil, dan melihat profil kandidat secara lengkap dengan cara memilih menu kandidat.

Jika siswa sudah memilih, maka pada bagian bawah gambar akan ada keterangan anda sudah memilih, yang artinya pemilik akun sudah memberikan hak suaranya. Apabila siswa yang telah memberikan hak suara kemudian menekan tombol back atau kembali pada browser, maka suara akan tetap masuk ke kandidat yang sudah dipilih sebelumnya, dan pengguna tidak bisa merubah atau memberikan voting lagi. 


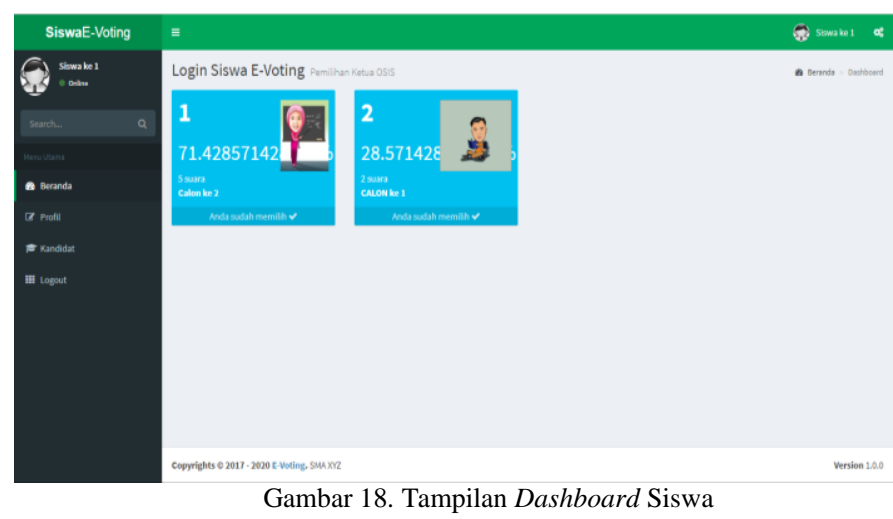

Hasil dari voting pemilihan ketua OSIS dapat dilihat tanpa harus login kedalam aplikasi seperti yang terlihat pada gambar 19 sehingga pemilihan ketua OSIS bisa menjadi lebih transparan.

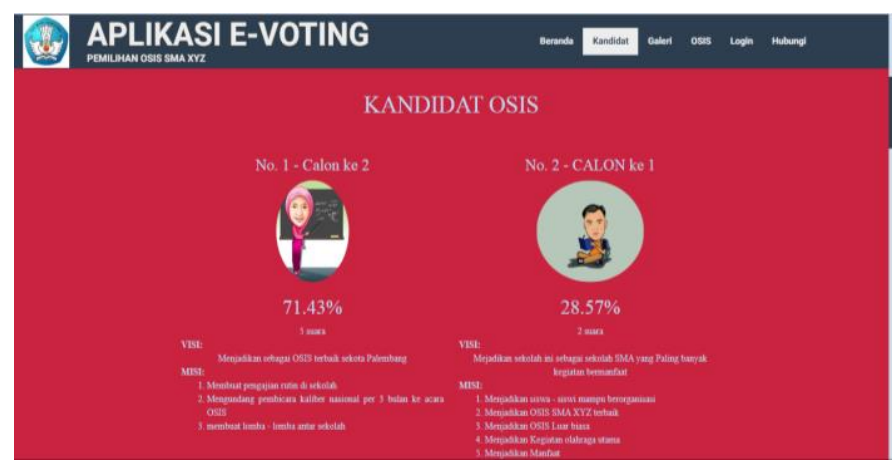

Gambar 19. Tampilan Hasil Voting

\section{Pengujian sistem}

Pada tahapan pengujian sistem, penulis menguji perangkat lunak dari sisi fungsionalitas sistem apakah sistem sudah berjalan dengan baik dan benar, tanpa melakukan uji desain maupun uji kode program. Pengujian ini menggunakan metode blackbox. Blackbox adalah metode pengujian perangkat lunak yang berfungsi untuk menguji fungsionalitas dari aplikasi yang telah dibuat untuk mengetahui fungsi yang bertentangan dengan struktur internal atau kinerja. Test case bertujuan untuk menunjukan fungsi perangkat lunak tentang cara beroperasinya, apakah pemasukan data keluaran telah berjalan sebagaimana yang diharapkan dan apakah informasi yang disimpan secara eksternal dijaga kemutakhirannya [9].

Pengujian ini berfungsi untuk mengetahui apakah fungsifungsi masukan dan keluaran dari sistem sudah sesuai dengan apa yang dibutuhkan. Pengujian ini sendiri menggunakan 1 akun administrator dan 5 akun siswa. Adapun hasil pengujian yang dilakukan baik menggunakan akun administrator maupun akun siswa ditunjukkan pada tabel 1 .
Tabel 1. Pengujian Blackbox

\begin{tabular}{|c|c|c|c|}
\hline No & Skenario Uji & $\begin{array}{l}\text { Hasil Yang } \\
\text { diharapkan }\end{array}$ & Keterangan \\
\hline 1 & $\begin{array}{l}\text { Login Ke } \\
\text { dalam Sistem } \\
\text { dengan } \\
\text { password } \\
\text { yang benar } \\
\text { dan salah }\end{array}$ & $\begin{array}{l}\text { Jika benar akan } \\
\text { masuk kedalam } \\
\text { sistem dan } \\
\text { menampilkan } \\
\text { dashboard, jika } \\
\text { salah aka nada } \\
\text { notifikasi jika } \\
\text { password yang } \\
\text { dimasukkan salah }\end{array}$ & Berhasil \\
\hline 2 & $\begin{array}{l}\text { Memberikan } \\
\text { hak suara }\end{array}$ & $\begin{array}{l}\text { Jika pengguna } \\
\text { menekan link } \\
\text { pilih disalah satu } \\
\text { gambar calon } \\
\text { ketua OSIS maka } \\
\text { polling akan } \\
\text { bertambah sesuai } \\
\text { persentasi suara. }\end{array}$ & Berhasil \\
\hline 3 & $\begin{array}{l}\text { Menambah } \\
\text { akun siswa } \\
\text { dan } \\
\text { administrator }\end{array}$ & $\begin{array}{l}\text { Jika administrator } \\
\text { menambahkan } \\
\text { akun siswa } \\
\text { maupun admin } \\
\text { lainnya, maka } \\
\text { akun tersebut } \\
\text { dapat digunakan } \\
\text { untuk } \\
\text { memberikah suara } \\
\text { untuk siswa, dan } \\
\text { mengelola sistem } \\
\text { untuk akun admin }\end{array}$ & Berhasil \\
\hline 4 & $\begin{array}{l}\text { Mengaktivasi } \\
\text { akun siswa }\end{array}$ & $\begin{array}{l}\text { Jika administrator } \\
\text { mengaktivasi } \\
\text { akun siswa, maka } \\
\text { sistem akan } \\
\text { menerima } \\
\text { permintaan login } \\
\text { siswa }\end{array}$ & Berhasil \\
\hline 5 & $\begin{array}{l}\text { Menambah } \\
\text { data calon } \\
\text { ketua OSIS } \\
\text { dan visi misi }\end{array}$ & $\begin{array}{l}\text { Sistem akan } \\
\text { menampilkan data } \\
\text { diri, foto dan visi } \\
\text { misi dari calon } \\
\text { ketua OSIS ke } \\
\text { dashboard siswa } \\
\text { untuk dipilih dan } \\
\text { menampilkan data } \\
\text { di halaman depan } \\
\text { dari sistem agar } \\
\text { bisa dilihat } \\
\text { pengguna luar. }\end{array}$ & Berhasil \\
\hline
\end{tabular}

Setelah pengujian berhasil dilakukan, maka tahapan terakhir dari siklus prototype ini adalah menyerahan sistem ke pelanggan. Dalam tahapan ini pelanggan akan mencoba sistem dan akan memberikan umpan balik. Pada tahap ini dilakukan evaluasi terhadap prototype yang telah dibangun dengan 
pengguna. Apabila sudah sesuai dengan kebutuhan dari pelanggan maka sistem ini akan langsung dapat digunakan sepenuhnya. Akan tetapi karena mplementasi dari sistem ini menggunakan data dummy, dimana ujicoba yang dilakukan hanya sebatas didalam laboratorium komputer, maka tahapan terakhir tidak dapat dilakukan.

\section{PENUTUP}

Kesimpulan dari Aplikasi E-voting berbasis web ini antara lain terbukti mampu menghasilkan sistem yang fektif dan efisien karena hasil pemilihan dapat langsung di proses dan dapat langsung diketahui hasilnya siapa yang akan menjadi ketua OSIS berikutnya. Sistem ini juga mampu berjalan dengan baik sesuai dengan pengujian menggunakan metode blackbox yang telah dilakukan. Sistem ini juga terbukti dapat memudahkan para siswa dalam menentukan pilihan karena bisa dilakukan dari sekolah maupun dari rumah serta ramah lingkungan karena penggunaan kertas sudah tidak diperlukan sebanyak saat pemilihan masih dilakukan secara manual.

Adapun saran yang penulis berikan untuk penyempurnaan sistem ini kedepannya yaitu perlunya tambahan sistem keamanan data, seperti enkripsi. Agar informasi yang mengalir dari para pemilih ke server dapat lebih terjaga kerahasiannya.

\section{DAFTAR PUSTAKA}

[1] Kasemin kasiyanto. 2015. Agresi Perkembangan Teknologi Informasi. Prenada Media Group: Jakarta.

[2] Jovan, FN. 2007. Panduan praktis Membuat WEB dengan PHP untuk Pemula. Jakarta: Media Kita.
[3] Surat Keputusan Direktur Jendral Pendidikan Dasar dan Menengah Nomor 226/C/Kep/0/1993

[4] Nahado Royhan. 2015. Bumbu Bumbu Membuat Website: Cara Membuat Website Cantik dan Mudah. https://books.google.co.id, diakses tanggal 9 november 2019.

[5] Faisal reza M. 2016.Seri Belajar ASP.NET : ASP.NET MVC Untuk Pemula. Ebook.

[6] Kirana Chandra, Suci Amalia. 2018. Rancang Bangun Aplikasi MVoting Untuk Pemilihan Ketua OSIS Di Ma Darussalam Pangkalpinang Berbasis Smartphone Android. Jurnal Informatika Vol. 1, oktober 2018.

[7] R Prananda, H Anra, HS Pratiwi. 2017. Rancang Bangun Aplikasi EVoting Berbasis Android (Studi Kasus: Pemilihan Ketua Organiasi di Lingkungan Fakultas Teknik Universitas Tanjungpura). Jurnal Sistem dan Teknologi Informasi, vol. 5, No. 1, hal. $17-21$.

[8] D Lavarino. 2016. Rancang Bangun E-Voting Berbasis Website di Universitas Negeri Surabaya. Jurnal Manajemen Informasi. Vol.6, No.1, hal. 72-81

[9] FA Syam, Y Darmayunata. 2019. Perancangan Sistem E-Voting Untuk Pemilihan Ketua OSIS SMP Negeri 10 Pekanbaru. Jurnal Sistem Informasi. Vol. 1, No. 2, hal. 75-85.

[10] MM Purba. 2018. Perancangan E-Voting Untuk Pemilihan Bem Berbasis Web. Jurnal Sistem Informasi, Vol. 5, No. 2, hal. 160-170.

[11] Roger, S. Pressman, Ph.D., 2012, Rekayasa Perangkat Lunak (Pendekatan Praktisi), Ed.7, diterjemahkan oleh Andi, Yogyakarta.

[12] D. Purnomo, "Model Prototyping Pada Pengembangan Sistem Informasi," J. Inform. Merdeka Pasuruan, vol. 2, no. 2, hal. 54-61, 2017.

[13] Munawar. 2005. Pemodelan Visual Dengan UML .Yogyakarta:Penerbit Graha Ilmu.

[14] Hendini, Ade. "Pemodelan Uml Sistem Informasi Monitoring Penjualan Dan Stok Barang (Studi Kasus: Distro Zhezha Pontianak)". Jurnal Khatulistiwa Informatika, Vol. IV, No. 2, hal 108-109, 2016.

[15] maruridi, ade djohar. 2014. Metode penelitian teknik informatika. Penerbit deepublish: Yogyakarta. 